\title{
Bioethanol Production from Sweet Potato (Ipomoea batatas L.) Flour using Co-Culture of Trichoderma sp. and Saccharomyces cerevisiae in Solid-State Fermentation
}

\author{
Manas Ranjan Swain ${ }^{1 *}$, Jyoti Mishra ${ }^{2}$ and Hrudayanath Thatoi ${ }^{1}$ \\ ${ }^{I}$ Department of Biotechnology, College of Engineering and Technology, Biju Patnaik University of Technology, \\ Bhubaneswar-751003, Orissa - India. ${ }^{2}$ Department of Biotechnology, North Orissa University, Baripada-757003, \\ Orissa - India
}

\begin{abstract}
The aim of this work was to study the optimiation of co-culturing of Trichoderma sp. and Saccharomyces cerevisiae (1:4 ratio) on sweet potato (Ipomoea batatas L.) flour (SPF) for the production of bio-ethanol in solid-state fermentation (SSF). Maximum ethanol (172 $\mathrm{g} / \mathrm{kg}$ substrate) was produced in a medium containing $80 \%$ moisture, ammonium sulphate $0.2 \%, \mathrm{pH} 5.0$, inoculuted with $10 \%$ inoculum size and fermented at $30^{\circ} \mathrm{C}$ for $72 \mathrm{~h}$. .Concomitant with highest ethanol concentration, maximum ethanol productivity (2.8 g/kg substrate/h), microbial biomass $\left(23 \times 10^{8}\right.$ CFU/ $\mathrm{g}$ substrate), ethanol yield (47 g/l00g sugar consumed) and fermentation efficiency ( $\left.72 \%\right)$ were also obtained under these conditions. Cell interaction was observed familiar between the viable cells of Trichoderma sp. and S. cerevisiae when co-cultured. Ethanol production ability by the co-culture was $65 \%$ higher than the single culture of S. cerevisiae from un-saccharified SPF.
\end{abstract}

Key words: Trichoderma sp., Saccharomyces cerevisiae, Sweet potato flour, Solid state fermentation

\section{INTRODUCTION}

As demand for the limited global supply of nonrenewable energy resources increases, the price of oil and natural gas keep increasing. A new biotechnological approach for the production of ethanol by fermentation from the renewable carbohydrate materials for use as an alternative liquid fuel has been attracting worldwide interest (Ward and Singh 2002). Thus, there is a growing interest to find alternative bioresources other than sugarcane/beet molassess and starchy crops such as cassava, sweet potato, and sweet sourghum for ethanol production.

Sweet potato (Ipomoea batatas L.) represents an important biomass resource for fuel alcohol production, because of its chemical composition and high density of starch, compared to other forms of biomass, and thus premise as an alternative bioresource for the production of ethanol through fermentation (Hang, et al. 1981, 1986; Roukas 1994). Sweet potato is a tropical and temperate regions' crop, normally found in Indian sub-continent (Woolfe 1992). It is used as a vegetable in the state of Odisha (Attaluri et al. 2010). Sweet potato is cheap, readily available in the local market and offers ease in product processing. It contains starch $(178 \mathrm{~g} / \mathrm{kg})$, total sugars $(26 \mathrm{~g} / \mathrm{kg})$ and protein $(3.2 \mathrm{~g} / \mathrm{kg})$ on fresh weight basis (Tian et al. 1991). The starch can be hydrolysed to monomer units of carbohydrates and

*Author for correspondence: manas.swain@gmail.com 
can be used by the microorganisms in fermentation process.

The production of industrial and fuel ethanol commonly involves three steps: 1) liquefaction of starch by $\alpha$ - amylase, 2) enzymatic sachharification of liquefied product to produce glucose, and 3) fermentation of glucose to ethanol (Sree et al. 2004). Commercial glucoamylase is used for the saccharification and represents a significant expense in the production process (Neves et al. 2006). Traditionally, the yeast, Saccharomyces cerevisiae has been used all over the world as the major ethanol producing microorganism (Lin and Shuzo 2006). Among the fermentation condition, SSF is found to more advanced and effective technology for the microbial production ethanol, using different substrates such as mahua flower (Mohanty et al. 2009), sweet sorghum (Kargi et al. 1985; Yu et al. 2008), apple pomace (Ngadi and Correia 1992), rice straw (Roslan et al. 2011), sugarcane bagasse (Shaibani et al. 2011) by S. cerevisiae. In recent years, however, research is focused on processes involving amylolytic mold Trichoderma sp. as coculture with $S$. cerevisiae, because of several better fermentation attributes as conversion of complex form of carbohydrates in to glucose and then conversion of glucose to ethanol and $\mathrm{CO}_{2}$ (Azevedo et al. 2000).

This study aimed at eliminating the enzymatic saccharification step by using a coculture of Trichoderma sp. as an amylolytic mold along with Saccharomyces cerevisiae (strain CET), an efficient and economical method for ethanol production (Manikandan and Viruthagiri 2009).

\section{MATERIALS AND METHODS}

\section{Organisms}

$S$. cerevisiae (strain CET) used in alcoholic fermentation factories was adopted as the experimental strain. Soil isolated Trichoderma sp. was a gift from Dr. R.C. Ray, Principal Scientist (Microbiology), Division of Post-harvest Technology, Central Tuber Crops Research Institute (Regional Centre). Bhubaneswar, India. Both the strains were maintained on the potato dextrose agar and stored at $4^{\circ} \mathrm{C}$ for further use.

\section{Preparation of Starter Culture}

S. cerevisiae was grown in $250 \mathrm{ml}$ Erlenmeyer flasks containing $100 \mathrm{ml}$ sterilized yeast extract- nutrient broth medium, (YENB) with sugar concentration of $12 \%(\mathrm{w} / \mathrm{v})$ and the $\mathrm{pH}$ was adjusted to 5.5 by dilute $\mathrm{HCl}$. The Trichoderma $\mathrm{sp}$. was grown in $250 \mathrm{ml}$ Erlenmeyer flasks containing $100 \mathrm{ml}$ sterilized Trichoderma specific medium (g/l: $\mathrm{MgSO}_{4} 0.2, \mathrm{~K}_{2} \mathrm{HPO}_{4} 0.9, \mathrm{KCl}, 0.3 ; \mathrm{NH}_{4} \mathrm{NO}_{3}$, 3.0; glucose, 3.0; chloromophenicol, 0.25; pentachloro nitrobenzene, 0.2; Rose Bengal, 1.5; Captan, 0.2; Metaloxyl, 1.6 and $\mathrm{pH}$ adjusted to 5.5) (Swain and Ray 2009). The cultures were grown at $30^{\circ} \mathrm{C}$ for $24 \mathrm{~h}$. Trichoderma sp. and $S$. cerevisiae cultures were used in 1:4 proportions as starter culture for ethanol production, respectively.

\section{Substrate}

Fresh sweet potato was collected from the local market of Bhubaneswar, Capital of Odisha, India during February-March, 2010. It was washed thoroughly to remove the dust and other debris, peeled off and chopped into small pieces. It was then placed in oven at $70^{\circ} \mathrm{C}$ for $24 \mathrm{~h}$ till the moisture content reduced to $11-12 \%$ and grinded with mixture grinder (Bajaj, Pvt. Ltd, India) with 200-250 rpm in to flour. The powder was sieved through a steel mesh to get $2-3 \mathrm{~mm}$ diameter size of sweet potato flour. The sweet potato flour was stored in air tight container for further use.

\section{Fermentation Medium}

Fifty grams of sweet potato flour supplemented with $0.2 \% \mathrm{NH}_{4} \mathrm{Cl}$ was placed in $1000 \mathrm{ml}$ Roux bottles $(132 \mathrm{~mm} \times 275 \mathrm{~mm})$ and moistened with appropriate amount of distilled water in order to contain $70 \%$ moisture. The $\mathrm{pH}$ of the substrate was adjusted to 6.0 with $1 \mathrm{~N} \mathrm{NaOH}$. The content was pressure-cooked at $120^{\circ} \mathrm{C}$ for $20 \mathrm{~min}$ and inoculated with Trichoderma spp. and yeast starter culture $\left[10 \%\right.$, v/w $\left(2 \times 10^{9}\right.$ Colony Forming Unit $(\mathrm{CFU}) / \mathrm{ml})$ and $3 \times 10^{9} \mathrm{CFU} / \mathrm{ml}$, respectively at 1:4 ratio. The Roux bottles, in triplicate, were incubated at $30^{\circ} \mathrm{C}$ under stationary conditions for $120 \mathrm{~h}$.

\section{Study of Fermentation Parameters}

(1) Moisture content: A series of Roux bottles containing $50 \mathrm{~g}$ SPF were moistened with an appropriate amount of distilled water in order to contain 40, 50, 60, 70, 80 and $90 \%$ moisture. The flasks, in triplicate, were inoculated and incubated at $30{ }^{\circ} \mathrm{C}$ for $72 \mathrm{~h}$ in a BOD incubator (Rami Pvt. Ltd, Mumbai, India).

(2) Initial $\mathrm{pH}$ : The substrate consisting of $50 \mathrm{~g}$ SPF with $70 \%$ moisture and a $\mathrm{pH} \mathrm{3,4,5,6,7}$ and 8 
were inoculated and incubated as mentioned above.

(3) Temperature: The medium (50 g SPF, moisture $70 \%$ and $\mathrm{pH}$ 6.0) was inoculated for $72 \mathrm{~h}$ and incubated at different temperatures $\left(20\right.$ to $40{ }^{\circ} \mathrm{C}$ ).

(4) Nitrogen sources: The fermentation medium (50 g SPF, moisture $70 \%$ and $\mathrm{pH}$ 6.0) was supplemented with different nitrogen sources (Urea, Ammonium molybdate, Ammonium sulphate and Potassium nitrate) at $0.2 \%$ and incubated at $30^{\circ} \mathrm{C}$ for $72 \mathrm{~h}$.

\section{Analytical Techniques}

At appropriate time intervals, fermentation bottles were removed and the contents were analyzed. The number of living cells was determined by plate counting $S$. cerevisiae that was cultivated on YENA medium at $30{ }^{\circ} \mathrm{C}$ for $24 \mathrm{~h}$. The fermented mash in each Roux bottle was mixed with $150 \mathrm{ml}$ distilled water $(1: 3, w / v)$ and the mixture was shaken on a rotary shaker (Remi Pvt. Ltd., Mumbai, India) at $250 \mathrm{rpm}$ at $30{ }^{\circ} \mathrm{C}$ for $30 \mathrm{~min}$ in order to extract the ethanol and the whole mash was distilled to collect the ethanol (Swain et al. 2007 ). Ethanol concentration of the fermentation liquid was determined by measuring the specific gravity of the distillate according to Amerine and Ough (1984). The ethanol yield was expressed as $\mathrm{g}$ ethanol/ $100 \mathrm{~g}$ sugar consumed. Fermentation efficiency was calculated by dividing the sugar consumed during the fermentation by the initial sugars and multiplying the results by 100 . The concentrations of the total sugar (glucose, fructose, sucrose and maltose) in the flour and in the fermentation broth were determined as glucose equivalent by Anthrone method (Mahadevan and Sridhar 1999). The other proximate compositions such as starch, crude protein, crude fiber and ash were estimated as per the standard AOAC procedure (1984). The $\mathrm{pH}$ was measured by a $\mathrm{pH}$ meter (Systronics, Ahmedabad, India) using glass electrode. Fermentation kinetics were studied as per the formulae given by Bailey and Ollis (1986).

\section{Population Count}

Yeast population in the fermented mash was calculated by serially diluting the sterile in the distilled water and plating the suitable dilutions $\left(10^{8}-10^{9}\right)$ on YENA solidified medium on Petri plates $(18 \mathrm{~mm} \times 150 \mathrm{~mm})$. Data were given as mean of six replicates. Similarly, the Trichoderma sp. population was calculated on Trichoderma specific medium as mentioned above.

\section{Determination of Moisture of the Substrate}

The moisture content of the substrate was analyzed by a Mettler Lp16 Infra-Red analyser.

\section{RESULTS AND DISCUSSION}

The production of ethanol from sweet potato flour by co-culture of $S$. cerevisiae and Trichoderma sp. in SSF is shown in Figure 1. The concentration of ethanol increased with the increase of fermentation time and yeast biomass. The maximum ethanol $(154 \pm 4 \mathrm{~g} / \mathrm{kg}$ substrate) concentration $(95 \%)$ was obtained after $72 \mathrm{~h}$ of incubation. Apparently the residual sugar was not rapidly and consistently produced during the first $72 \mathrm{~h}$, then it decreased slowly (Fig. 1). The residual sugar concentration behaviour was more or less constant along the fermentation. In a previous study, maximum ethanol concentration of 193 and $205 \mathrm{~g} / \mathrm{kg}$ flowers were obtained when free and immobilized yeast cells were grown in mahula flower (mahula flower: water, 1:5, w/v), respectively after $96 \mathrm{~h}$ in submerged shake-flask fermentation (Swain et al. 2007). Hang et al. (1981, 1986) reported maximum ethanol concentration of $43 \mathrm{~g} / \mathrm{kg}$ apple pomace and $53.5 \mathrm{~g} / \mathrm{kg}$ grape pomace for various yeast strains grown in SSF, whereas Roukas (1994) found that maximum ethanol $(160 \pm 3 \mathrm{~g} / \mathrm{kg}$ dry pods) was obtained when $S$. cerevisiae was grown on carob pods (Ceratonia siliqua) after $48 \mathrm{~h}$ of fermentation. Kiran Sree et al. (1999) reported highest ethanol concentration of $50 \mathrm{~g} / \mathrm{kg}$ substrate (sweet sorghum and sweet potato) in SSF at $37^{\circ} \mathrm{C}$ using a thermotolerant strain of $S$. cerevisiae. Upscaling experiments using $1.0 \mathrm{~kg}$ cassava starch showed that Stargen (granular starch hydrolyzing enzyme mix with $\alpha$-amylase and glucoamylase activities) to starch ratio of $1: 100(\mathrm{w} / \mathrm{w})$ could yield around $558 \mathrm{~g}$ ethanol/ $\mathrm{kg}$ starch, with a high fermentation efficiency of $98.4 \%$ (Shanavas et al. 2011). There were some possible reasons for these differences, including the strain of $S$. cerevisiae used, biochemical composition of the substrate, fermentation system and the condition under which the fermentation took place (Henk and Linden 1996, Chen et al. 2007). The viable cell numbers ( $S$. cerevisiae and Trichoderma sp.) increased from $4 \times 10^{8} \mathrm{CFU} / \mathrm{g}$ substrate $(0 \mathrm{~h})$ to $22.5 \times 10^{9} \mathrm{CFU} / \mathrm{g}$ substrate $(72 \mathrm{~h})$ after which it decreased drastically at $96 \mathrm{~h}\left(2 \times 10^{8} \mathrm{CFU} / \mathrm{g}\right.$ substrate). The decline in biomass concentration could be due to reduced substrate availability and 
the inhibitory effect of ethanol on the cells (Ward et al. 2006; Ward and Singh, 2002). Further, the concentration of residual sugars decreased during the fermentation coinciding with an increase in biomass and ethanol production (Fig. 1). The concentration of residual sugars fell rapidly and consistently during the first $72 \mathrm{~h}$ of fermentation, after which it decreased slowly. This was due to rapid increase in biomass and ethanol concentration, observed at the same time. At the time $(72 \mathrm{~h})$ when the maximum concentration of ethanol was achieved, 78\% of sugar consumed was converted to ethanol.

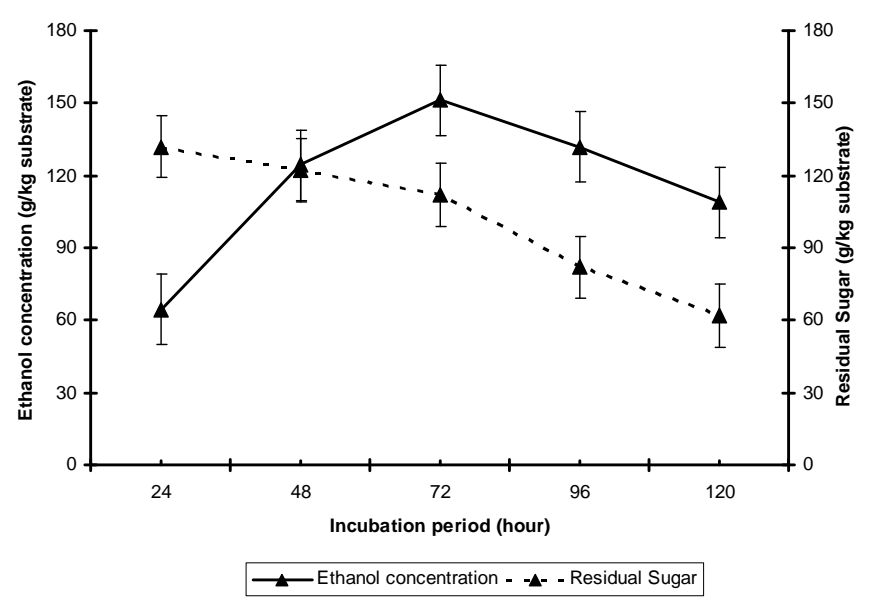

Figure1 - Role of incubation period on ethanol concentration and sugar consumption by Trichoderma sp. and Saccharomyces cerevisiae as co-culture in solid-state fermentation using sweet potato flour.

\section{Effect of Moisture Content}

Moisture content is one of the important factors that affect the performance of SSF. As shown in Figure 2, the ethanol concentration, ethanol productivity, ethanol yield and fermentation efficiency were increased significantly with the increase in moisture content. The highest value of fermentation parameters were achieved at a moisture level of $80 \%$. Roukas (1994) reported a moisture level of $70 \%$ was the best to achieve ethanol concentration $(160 \pm 3 \mathrm{~g} / \mathrm{kg})$ from carob pod in SSF. Similarly, Kargi et al. (1985) and Ngadi and Correia (1992) reported that the maximum ethanol production was obtained from sweet sorghum and apple pomace in SSF at a moisture level of 70 and $85 \%$, respectively.

Decreasing the moisture level from 80 to $40 \%$ resulted in a decrease in all kinetic parameters (ethanol concentration, ethanol productivity, ethanol yield and fermentation efficiency). This was because an optimum moisture level $(80 \%$ in the present study) was essential for sustaining the optimum growth of microorganisms and thereby ethanol production. The decrease in the moisture level is to a certain extent advantageous since the chance of contamination of fermentation is reduced. However, there is a lower limit of moisture content below which microbial cells may not function to produce ethanol (Alan Eddy and Barnett 2007). Likewise, above $70 \%$ moisture content in SSF, there was a decrease in ethanol accumulation. This might be due to decrease in the porosity, lower oxygen transfer and poor aeration inside the substrate mass under the stationary fermentation condition (Ray et al. 2008).

\section{Effect of Initial pH}

The effect of initial $\mathrm{pH}$ on kinetic parameters of sweet potato substrate fermentation is shown in Figure 3. The fermentation parameters increased drastically with the increase in $\mathrm{pH}$ up to 5.0 and decreased beyond this value. On the other hand, ethanol yield and ethanol productivity remained more or less same over the $\mathrm{pH}$ range of 5.0 to 6.0, and decreased marginally above 6.0 (data not shown). The maximum ethanol concentration $(140.0 \pm 4 \mathrm{~g} / \mathrm{kg}$ sweet potato substrate), ethanol productivity $(3.13 \mathrm{~g} / \mathrm{kg} / \mathrm{h})$, ethanol yield $(58.44$ $\mathrm{g} / 100 \mathrm{~g}$ sugar consumed) and fermentation efficiency $(72.1 \%)$ were obtained in the culture 
grown at pH 5.0. Roukas (1994) studied the effect of $\mathrm{pH}$ on ethanol production from carob pod by $S$. cerevisiae and found that the maximum ethanol concentration, ethanol yield, and fermentation efficiency were obtained at $\mathrm{pH}$ 4.5. Yeasts have a $\mathrm{pH}$ optimum between 4.0 and 6.0, and can grow in a large $\mathrm{pH}$ range of 2.5 to 8.5 (Narendranath and Power 2005).

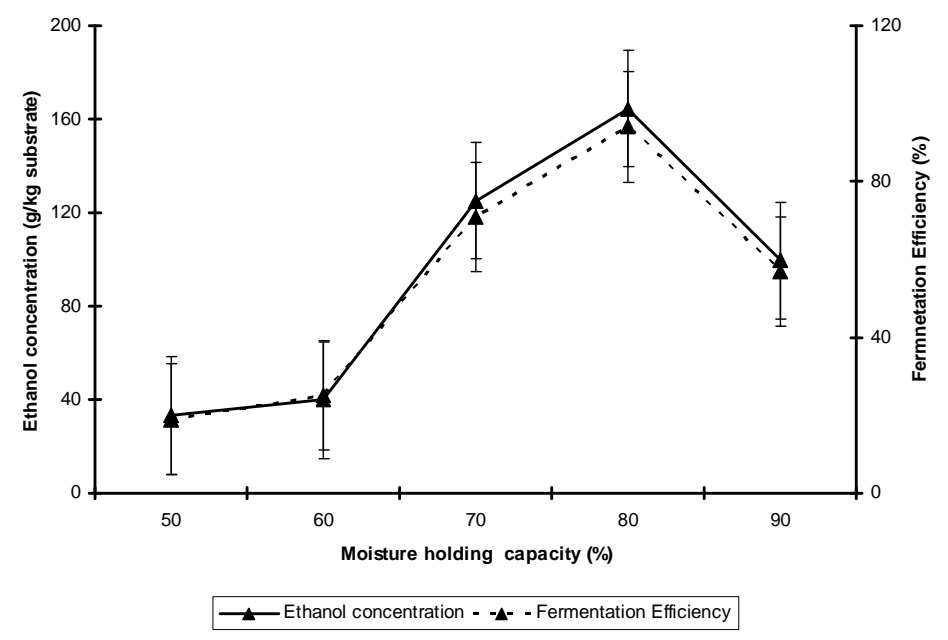

Figure 2 - Effect of moisture content (\%) on ethanol concentration and ethanol fermentation efficiency by Trichoderma sp. and Saccharomyces cerevisiae as co-culture in solid-state fermentation of sweet potato flour.

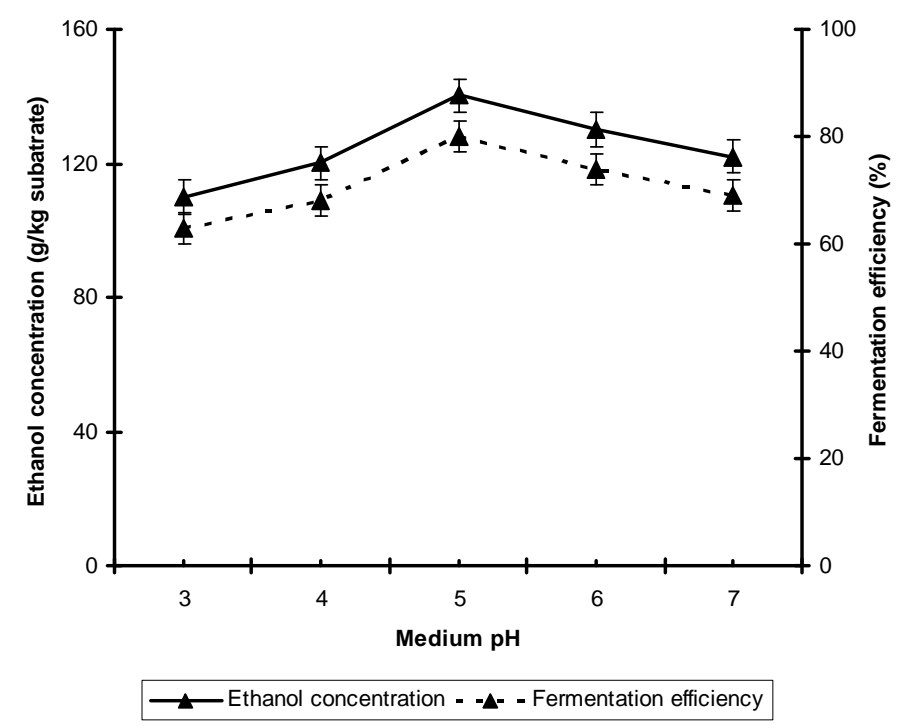

Figure 3 - Effect of initial $\mathrm{pH}$ on ethanol concentration and ethanol fermentation efficiency by Trichoderma sp. and Saccharomyces cerevisiae as co-culture in solid-state fermentation of sweet potato flour

\section{Effect of Temperature}

As shown in Figure 4, increasing the fermentation temperature from 20 to $40{ }^{\circ} \mathrm{C}$ significantly affected the ethanol concentration, ethanol productivity and fermentation efficiency. The ethanol yield decreased at temperature values 
lower or higher than 25 to $30{ }^{\circ} \mathrm{C}$. The ethanol concentration, ethanol productivity and fermentation efficiency increased with the increase in fermentation temperature from 20 to $30^{\circ} \mathrm{C}$ and decreased gradually between 30 and $35{ }^{\circ} \mathrm{C}$ and drastically above $35^{\circ} \mathrm{C}$. This was probably due to the decrease in viable cell number above $30{ }^{\circ} \mathrm{C}$.
Temperature in the range of 25 to $30{ }^{\circ} \mathrm{C}$ is commonly found optimum for mesophillic $S$. cerevisiae strain for the production of ethanol in SSF of various substrates, i.e., apple pomace (Hang et al. 1986), carob pod (Roukas 1994), sweet sorghum (Mamma et al. 1996), etc.

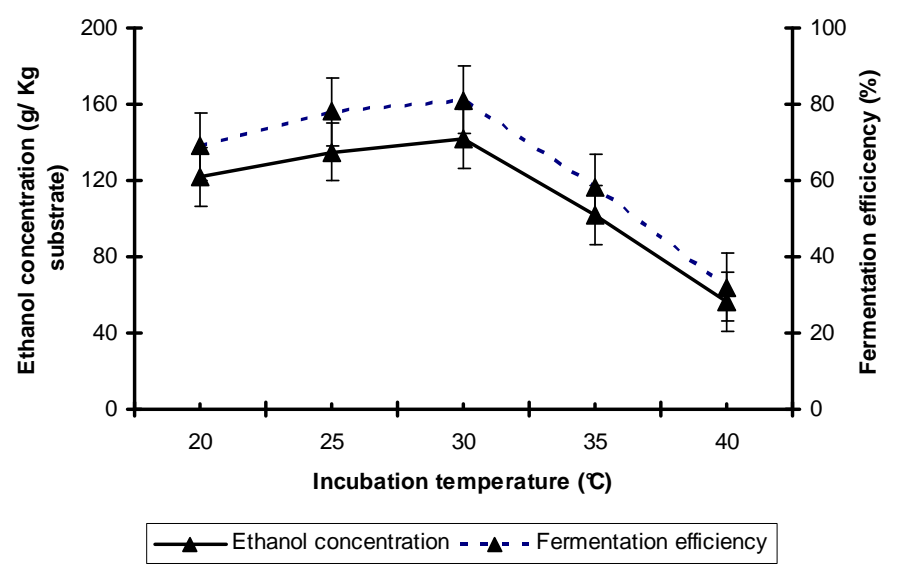

Figure 4 - Effect of initial incubation temperature $\left({ }^{\circ} \mathrm{C}\right)$ on ethanol concentration and ethanol fermentation efficiency by Trichoderma sp. and Saccharomyces cerevisiae as co-culture in solid-state fermentation of sweet potato flour.

\section{Effect of Different Nitrogen Sources}

Microorganisms utilize nitrogen to metabolize the nitrogenous substances for their growth and activity (Beltran et al. 2007). From Figure 5, it could be concluded that maximum ethanol production was obtained at $0.2 \%$ ammonium sulphate (172 $\mathrm{g} / \mathrm{kg}$ substrate), followed by potassium nitrate. The ethanol production was drastically reduced when urea and ammonium molybdate were taken as the sole nitrogen sources in the fermentation medium. This could be due to the inhibitory activity of the nitrogen sources. Benerji et al. (2010) reported higher ethanol production $(13.29 \%, \mathrm{w} / \mathrm{v})$ in the presence of urea $(0.06 \%)$ from mahula flower by using $S$. cerevisiae. In another study, Laopaiboon et al. (2009) reported higher ethanol production (120.68 $\pm 0.54 \mathrm{~g} / \mathrm{l})$ in the presence of peptone $(5 \mathrm{~g} / \mathrm{l})$ and yeast extract $(3 \mathrm{~g} / \mathrm{l})$ in sweet sorghum juice. Ammonium sulphate along with vitamins and trace elements increase ethanol productivity up to 57\% (Guebel et al. 1992).

Finally, all the optimized parameters $(\mathrm{pH}, 5.0$; temperature, $30^{\circ} \mathrm{C}$; initial moisture content $80 \%$, incubation period, $72 \mathrm{~h}, \quad\left(\mathrm{NH}_{4}\right)_{2} \mathrm{SO}_{4}, \quad 0.2 \%$; inoculums size, $10 \%$ ) were taken together for the production of ethanol. As evident from Table 1, the ethanol concentration gradually increased up to $72 \mathrm{~h}(172 \mathrm{~g} / \mathrm{kg}$ substrate) and decreased gradually thereafter. Maximum ethanol productivity (2.8 $\mathrm{g} / \mathrm{kg}$ substrate/h), microbial biomass $\left(23 \times 10^{8}\right.$ CFU/g substrate), ethanol yield (47 g/100g sugar consumed) and fermentation efficiency $(72 \%)$ were also obtained at these parametric levels.

The average production ( $\mathrm{m}$ ton/ha) of different bioethanol crops under irrigated condition in India are as follows: sugarcane (8-12), sweet sorghum (2-3), cassava (12-18), and sweet potato $(8-10)$ (Swain et al. 2007; Ward et al. 2006). The sweet potato occupies $24 \%$ among the most suitable substrate for the bioethanol production. The cost (US\$1 = INR 44.8 basis) of ethanol production $/ \mathrm{kg}$ substrate has been estimated for sugar cane (0.27), sweet sorghum (0.29), cassava (0.55) and sweet potato $(0.31)$. In India, total production of sweet potato in the year 2006 was $1,23,000 \mathrm{~m}$ tones (Ward et al. 2006). The sweet potato could serve potential feedstock for bioethanol in tropical countries such as India, Pakistan, Indonesia and Australian continent (Kar et al. 2004). 


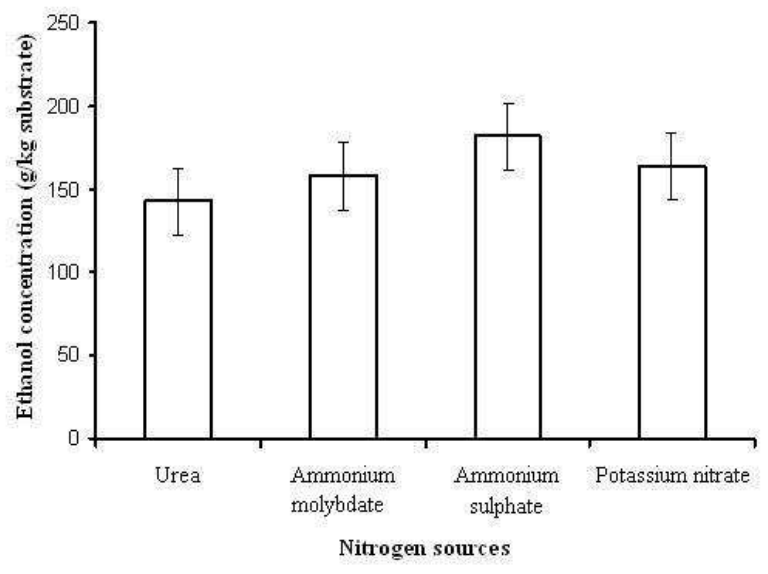

Figure 5 - Effect of nitrogen source (0.2\%) on ethanol concentration by Trichoderma sp. and Saccharomyces cerevisiae as co-culture in solid-state fermentation of sweet potato flour.

Table 1 - Production of Ethanol concentration with optimal conditions evaluated for the Trichoderma sp. and Saccharomyces cerevisiae as co-culture.

\begin{tabular}{|c|c|c|c|c|}
\hline Substrate concentration & & $50 \mathrm{~g}$ & & \\
\hline $\mathrm{pH}$ & & 5.0 & & \\
\hline Temperature & & $30^{\circ} \mathrm{C}$ & & \\
\hline Inoculums size & & $10 \%(1: 4$, Trichod & . : S. ce & \\
\hline Moisture content & & $80 \%$ & & \\
\hline Incubation period & & $72 \mathrm{~h}$ & & \\
\hline Nitrogen source & & $\left(\mathrm{NH}_{4}\right)_{2} \mathrm{SO}_{4} 0.2 \%$ & & \\
\hline \multicolumn{5}{|c|}{ Production of ethanol ( $\mathrm{g} / \mathrm{kg}$ substrate) in different incubation period } \\
\hline $48 \mathrm{~h}$ & $72 \mathrm{~h}$ & $96 \mathrm{~h}$ & $120 \mathrm{~h}$ & $144 \mathrm{~h}$ \\
\hline 135 & 172 & 142 & 119 & 105 \\
\hline
\end{tabular}

\section{CONCLUSION}

Sweet potato flour is available in plenty in the Asia-Pacific regions, including in Orissa (India) but it's commercial potential for fuel ethanol has not been fully explored. Being a cheap source of fermentable carbohydrate bio-resource, it could be employed for the production of fuel ethanol. In the present investigation, maximum ethanol production from sweet potato flour in SSF was obtained at $72 \mathrm{~h}$ in co-culture fermentation. Ethanol production ability by the co-culture ( $S$. cerevisiae and Trichoderma sp.) was $65 \%$ higher than the single culture of $S$. cerevisiae from un-saccharified sweet potato flour whereas ethanol concentration was almost same in single (S. cerevisiae) culture fermentation from the enzyme saccharified sweet potato flour. This saved considerable time and energy besides ease in operation and recovery process that would be advantageous for overall SSF. However, further studies would be needed to standardised the protocols and economize the fuel ethanol production from sweet potato in comparison to other substrates such as sugarcane/beet molasses.

\section{ACKNOWLEDGMENTS}

The Department of Science and Technology-Govt. of Orissa is gratefully acknowledged for its financial support of this project (Project no.3897/ST, Bhubaneswar dated 07/08/10).

\section{REFERENCES}

Alan Eddy A, Barnett JA. A history of research on yeast 11 . The study of salt tolerant: the first 90 years, simple and fascinated diffusion. Yeast. 2007; 24: 1023 - 1092.

Amerine MA, Ough CS. Wine and must analysis. New York, USA: Wiley; 1984. 
Attaluri S, Janardhan KV, Light A. Sustainable sweet potato production and utilization in Orissa, India. Proceedings of a workshop and training held in Bhubaneswar, Orissa, India, 17-18 Mar 2010. Bhubaneswar, India. International Potato Center (CIP); 2010.

Azevedo AMC, Marco JLD, Felix CR. Characterization of an amylase produced by a Trichoderma harzianum isolate with antagonistic activity against Crinipellis perniciosa, the caysual agent of witch' broom of cocoa. Fems Microbial Lett. 2000; 188: 171-175.

Bailey JE, Ollis DF. Biochemical engineering fundamentals. New York: McGraw- Hill, 1986.

Beltrn G, Rozas N, Mas A, Guillamom J. Effect of low temperature fermentation on yeast nitrogen metabolism. World J Microbiol Biotechnol. 2007; 23: $809-815$.

Benerji DSN, Rajini K, Srinivasa Rao B, Banerjee DRN, Swaroopa Rani K, Rajkumar G, Ayyanna C. Studies on physico-chemical and nutritional parameters for the production of ethanol from mahua flower (Madhuca indica L.) using Saccharomyces cerevisiae - 3090 through submerged fermentation (smf). J Microbial Biochem Technol.2010; 2: 46-50.

Chen $\mathrm{HZ}, \mathrm{Xu} \mathrm{J}, \mathrm{Li} \mathrm{ZH}$. Temperature cycling to improve the ethanol production with solid-state simultaneous saccharification and fermentation. Appl Biochem Microbiol. 2007; 43: 57-60.

Guebel DV, Cordenons A, Cascone O, Giulietti, AM, Nudel C. (Influence of the nitrogen source on growth and ethanol production by Pichia stipitis NRRL, Y7124. Biotechnol Lett. 1992; 14: 1193-1198.

Hang YD, Lee CY, Woodams EE. A solid-state fermentation system for production of ethanol from apple pomace. J Food Sci .1981; 47: 1851-1852.

Hang YD, Lee CY, Woodams EE. Solid-state fermentation of grape pomace for ethanol production. Biotechnol Lett.1986; 8: 53-56.

Henk LL, Linden JC. Solid state production of ethanol from sorghum. Appl Biochem Biotechnol. 1996; 54: 489-501.

Kar S, Chaudhury P, Ray RC. Comparative study of bioethanol production from sweet potato (Ipomoea batatas L.) and cassava (Manihot esculenta Crantz.) by acid enzyme hydrolysis. In: Root and tuber crops: nutrition, food security and sustainable environment, Proceeding of the symposium held on 29-31 October, 2004 at Regional Centre of Central Tuber Crops Research Institute. Bhubaneswar (India); 2004. p. 276-281.

Kargi F, Cureme JA, Sheehan JJ. Solid-state fermentation of sweet sorgum to ethanol. Biotechnol Bioeng. 1985; 27: 34-40.

Kiran Sree N, Sridhar M, Rao LV, Pandey A. Ethanol production in solid substrate fermentation using a thermotolerant yeast. Process Biochem. 1999; 34: $115-119$.
Laopaiboon L, Nunpeng S, Srinophakun P, Klanrit P, Laopaiboon P. Ethanol production from sweet sorghum juice using very high gravity technology: Effects of carbon and nitrogen supplementations. Bioresource Technol. 2009; 18: 4176- 4182.

Lin Y, Tanaka S. Ethanol fermentation from biomass resources: current state and prospects. Appl Microbiol Biotechnol. 2006; 69: 627-642,

Mahadevan A, Sridhar R. Methods in physiological plant pathology. $5^{\text {th }}$ ed. Sivakami Publication, Madras (India), 1999.

Mamma D, Koullas D, Fountoukidis G, Kekos BJ, Koukios E. Bioethanol from sweet sorghum: simultaneous Saccharification and fermentation of carbohydrates by a mixed microbial culture. Process Biochem. 1996; 31: 377-381.

Manikandan K, Viruthagiri T. Simulteneous saccharification and fermentation of wheat bran flour into ethanol using coculture of amylotic Asperigillus niger and thermotolerant Kluyveromyces marxianus. Front Chem Eng Chin. 2009; 3: 240-249

Mohanty SK, Behera S, Swain MR, Ray RC. Bioethanol production from Mahula (Madhuca latifolia L.) flowers by solid-state fermentation. Appl Energy. 2009; 86: 640-644.

Narendranath NV, Power R. Relationship between $\mathrm{pH}$ and medium dissolved solids in term of growth and metabolism of lactobacilli and Saccharomyces cerevisiae during ethanol production. Appl Environ. Microbiol. 2005; 171: 2239-2243.

Neves MAD, Kimura Shimizu N. Production of alcohol by simultaneous saccharification and fermentation of low grade wheat flour. Braz. Arch. Biol. Technol. 2006; 49: 489-490.

Ngadi MO, Correia LR. Solid-state ethanol fermentation of apple pomace as affected by moisture and bioreactor mixture speed. J. Food Sci. 1992; 57: 667-670.

Ray RC, Sahoo AK, Asano K, Tomita F. Microbial processing of agricultural residues for production of food feed and food, additives. In-Microbial biotechnology in agriculture and aquaculture, ed. R.C. Ray, Enfield New Hampshire: Science Publishers. vol. 2. 2008. p. 551-562.

Roukas T. Solid-state fermentation of carob pods for ethanol production. Appl. Microbiol. Biotechnol. 1994; 41: 296-301.

Roslan AM, Yee PL, Shah UKM, Aziz SA, Hassan MA. Production of bioethanol from rice straw using cellulase by local Aspergillus sp. Int. J. Agri. Res. 2011; 6: 188-193.

Shaibani N, Ghazvini S, Andalibi M R, Yaghmaei S. Ethanol production from sugarcane bagasse by means of enzymes produced by solid state fermentation method. World Academy Sci. Eng. Technol. 2011; 59: 1836-1839. 
Shanavas S, Padmaja G, Moorthy SN, Sajeev MS, Sheriff JT. Process optimization for bioethanol production from cassava starch using novel ecofriendly enzymes. Biomass Bioenerg. 2011; 35: 901909.

Sree NK, Sridhar M, Suresh K, Bannat IM, Rao LV. High alcohol production by repeated batch fermentation using an immobilized osmotolerant Saccharomyces cerevisiae. J. Ind. Microbiol. 2004; 24: 222-226

Swain MR, Kar S, Sahoo AK, Ray RC. Ethanol fermentation of mahula (Madhuca latifolia L.) flowers using free and immobilized yeast Saccharomyces cerevisiae. Microbiol. Res. 2007; 162: 93-98.

Swain, M.R. and Ray, R. C. Biocontrol and other beneficial activities of Bacillus subtilis isolated from owdung microflora. Microbiol. Res. 2009; 164: 121130.

Tian SJ, Rickard JE, Blanshard JMV. Physicochemical properties of sweet potato starch. J. Sci. Food Agri. 1991; 57 : $459-491$.
Ward OP, Singh A. Bioethanol technology: developments and perspectives. Adv. Appl. Microbiol. 2002; 51: 53-80.

Ward OP, Singh A, Ray RC. Production of renewable energy from agricultural and horticultural substrates and wastes. In: Ray RC, Ward OP, editors. Microbial biotechnology in horticulture. Enfield New Hampshire: Science Publishers; 2006, vol.1. p. 517558.

Woolfe JA. "Sweetpotato: an untapped food resource", Cambridge Univ. Press and the International Potato Center (CIP). Cambridge, UK, 1992.

Yu J, Zhang X, Tan T. Ethanol production by solid state fermentation of sweet sorghum using thermotolerant yeast strain. Fuel Processing Technol. 2008; 89: 1056-1059.
Received: October 01, 2011; Revised: March 06, 2012; Accepted: October 17, 2012. 


\section{PAGINA EM BRANCO}

